\title{
ВОПРОСЫ РЕАЛИЗАЦИИ АКТОВ МЕЖДУНАРОДНОЙ ОРГАНИЗАЦИИ ГРАЖДАНСКОЙ АВИАЦИИ В РОССИЙСКОЙ ФЕДЕРАЦИИ
}

\author{
(c) 2018 Вавилов Никита Сергеевич \\ кандидат юридических наук \\ старший преподаватель кафедры гражданского права и процесса юридического факультета \\ Марийский государственный университет \\ 424000, Республика Марий Эл, г. Йошкар-Ола, пл. Ленина, 1 \\ E-mail: nikitalawyer@rambler.ru
}

Статья опубликована при поддержке Российского фонда фундаментальных исследований - проект № 18-511-00003 «Акты органов международных организаций и их реализация в национальном законодательстве».

Влияние международного права на внутригосударственное продолжает оставаться актуальной темой в нынешней нестабильной мировой политической обстановке. На сегодняшний день гражданская авиация представляет собой динамично развивающуюся отрасль, являющуюся одной из самой сложной в вопросах взаимодействия человека и машины. Предметом исследования настоящей статьи являются правовые акты Международной организации гражданской авиации, а также вопросы реализации их на уровне Российской Федерации. В статье анализируются внутригосударственные нормативные акты, принимаемые на основе стандартов и практики ИКАО, делается вывод о достаточном правовом регулировании вопросов деятельности ИКАО в Российской Федерации. Методологической основой исследования послужил комплексный, системный подход к анализу процессов реализации актов ИКАО в России. В ходе исследования статуса, полномочий и деятельности ИКАО, процессов исполнения предписаний Чикагской конвенции использовались общефилософский метод, общенаучные методы познания (диалектический, системный, анализа и синтеза, индукции и дедукции), а также частнонаучные методы (сравнительно-правовой, формально-юридический, историко-правовой, социологический, системно-функциональный, статистический, теоретико-прогностический методы). Учитывая практически полное отсутствие исследований по тематике деятельности Международной организации гражданской авиации, представляется актуальным рассмотреть правовые аспекты реализации ее актов в Российской Федерации.

Ключевые слова: Международная организация гражданской авиации, национальная правовая система, Российская Федерация, нормативный правовой акт, реализация, международный стандарт, рекомендуемая практика, международный договор

На сегодняшний день, в эпоху «глобального» давления на Российскую Федерацию, как никогда встает вопрос о соблюдении норм международного права государствами, их влиянии на законодательства стран-участников, правовых механизмах соблюдения международного законодательства.

Соблюдение международных норм и правил - неотъемлемая часть политики Российской Федерации, направленной на улучшение жизни населения. Не осталась в стороне и сфера воздушных перевозок, регулируемая актами Международной организации гражданской авиации (далее - ИКАО).

В своем ежегодном послании Федеральному собранию Российской Федерации Президент
России Владимир Владимирович Путин отметил следующее: «Наша политика никогда не будет основываться на претензиях на исключительность, мы защищаем свои интересы, и уважаем интересы других стран, руководствуемся международным правом, считаем незыблемой ключевую роль ООН. Именно такие принципы и подходы позволяют нам выстраивать прочные, добрые и равноправные отношения с абсолютным большинством государств мира». Все это говорит о стремлении России к соблюдению норм международного права в любой сфере жизни общества [1].

Международная организация гражданской авиации (далее - ИКАО) является специализированным органом Организации Объединен- 
ных Наций. Данная организация была создана в результате подписания в Чикаго 7 декабря 1944 года Конвенции о международной гражданской авиации. ИКАО наблюдает за безопасным и планомерным ростом международных воздушных перевозок [2]. Как правильно отмечает В. Бордунов, «ИКАО создала мировой правопорядок, основанный на единообразных правилах и процедурах, обеспечивающих регулярность, эффективность и безопасность деятельности международного воздушного транспорта» [3].

Согласно ст. 44 Чикагской конвенции [4], в цели и задачи ИКАО входят разработка принципов и методов международной аэронавигации и содействие планированию и развитию международного воздушного транспорта с тем, чтобы: обеспечивать безопасное и упорядоченное развитие международной гражданской авиации во всем мире; поощрять искусство конструирования и эксплуатации воздушных судов в мирных целях; поощрять развитие воздушных трасс, аэропортов и аэронавигационных средств для международной гражданской авиации; удовлетворять потребности народов мира в безопасном, регулярном, эффективном и экономичном воздушном транспорте; предотвращать экономические потери, вызванные неразумной конкуренцией; обеспечивать полное уважение прав государств и справедливые для каждого государства возможности использовать авиапредприятия, занятые в международном воздушном сообщении; избегать дискриминации в отношении государств; способствовать безопасности полетов в международной аэронавигации; оказывать общее содействие развитию международной гражданской аэронавтики во всех ее аспектах.

В этих целях ИКАО уполномочена на проведение следующих мероприятий:

- принятие рекомендаций, международных стандартов, касающихся конструкции, характеристик самолетов и их оборудования, регламентирующих работу пилотов, летных экипажей, авиадиспетчеров, наземных служб и служб технического обслуживания, а также требований к безопасности работы международных аэропортов;

- разработка правил визуального пилотирования, пилотирования по приборам, аэронавигационные карты, регулирование в области авиационных телекоммуникаций, радиочастот и их безопасного использования;
- принятие мер по снижению антропогенной нагрузки на окружающую среду: снижение уровня шумов самолетов, снижение выбросов углекислого газа и иных вредных веществ;

- стандартизация в области таможенного, иммиграционного, санитарного дела;

- предотвращение вторжения в воздушное пространство, противодействие терроризму на воздушных судах и зданиях аэропортов, обеспечение безопасности воздушных перевозок.

Кроме вышеуказанных мероприятий, ИКАО выполняет запросы развивающихся стран на оказание помощи в сфере совершенствования авиатранспортных систем и подготовке персонала.

Структуру ИКАО составляют Ассамблея (представительный орган), Совет (руководящий орган) и Секретариат. Ассамблея проводится не реже одного раза в три года и созывается Советом. Каждое государство, имеющее членство в ИКАО, обладает одним голосом, решения Ассамблеи принимаются большинством поданных голосов. На заседаниях Ассамблеи рассматриваются вопросы о проделанной ИКАО работе в технической и экономической областях, Ассамблеей издаются руководящие документы для ИКАО относительно будущей деятельности. Секретариат ИКАО является постоянным органом, обеспечивающим деятельность Совета, Ассамблеи, региональных центров Организации.

Следует отметить, что в рамках своих обязательных функций Совет принимает международные стандарты и рекомендуемую практику, для удобства именует их приложениями к Чикагской Конвенции; и уведомляет все Договаривающиеся государства о принятых мерах. Стандартом признается требование, обязательное и единообразное применение которого необходимо для обеспечения безопасности или регулярности международной гражданской аэронавигации и который выполняется странами-участницами в соответствии с Чикагской Конвенцией. Рекомендуемая практика представляет собой техническое требование, обязательное и единообразное применение которого считается желательным для регулярности и эффективности международной гражданской аэронавигации.

Сегодня авторитет Международной организации гражданской авиации велик настолько, что государства, которые не присоединились к Чикагской конвенции, стараются адаптиро- 
вать свое внутреннее законодательство под нормы и правила Чикагской конвенции. Однако по отношению к конкретному государству определенный стандарт ИКАО не является окончательной правовой нормой, поскольку стандарт или правило поведения только означают обязательное правило поведения, а государство-участник обязуется самостоятельно исполнять предписание международной организации путем принятия собственных нормативных правовых актов.

Статья 38 Чикагской Конвенции содержит правило отклонения от международных стандартов и процедур. Так, любое государство, которое сочтет практически затруднительным придерживаться во всех отношениях каких-либо международных стандартов или процедур либо приводить свои собственные правила или практику в полное соответствие с какими-либо международными стандартами или процедурами после изменения последних либо которое сочтет необходимым принять правила или практику, имеющие какое-либо особое отличие от тех правил, которые установлены международным стандартом, незамедлительно уведомляет Международную организацию гражданской авиации о различиях между его собственной практикой и той, которая установлена международным стандартом. В случае изменения международных стандартов любое государство, которое не внесет соответствующих изменений в свои собственные правила или практику, уведомляет об этом Совет в течение шестидесяти дней после принятия поправки к международному стандарту или указывает меры, которые оно предполагает принять.

Деятельность Международной организации гражданской авиации обладает определенным нормотворческим потенциалом, что, так или иначе, отражается на национальной правовой системе государства, присоединившегося к Чикагской конвенции. Речь идет о принимаемых в государстве нормативных правовых актах, необходимых для исполнения вышеуказанной конвенции. Учеными-правоведами отмечается, что Российская Федерации имеет основательный опыт по исполнению решений Международной организации гражданской авиации [5]. Кроме того, как указывает Т.Л. Соловьева, «внедрение стандартов и рекомендуемой практики в национальную практику государств - очень сложная и трудоемкая задача, так как это связано прежде всего с различными политическими, экономическими, географическими, этническими и другими особенностями каждого государства. Именно поэтому для упрощения задачи стандарты и рекомендуемая практика оформлены в виде приложений к Чикагской конвенции» [6].

Международные стандарты и рекомендуемая практика ИКАО в Российской Федерации исполняются посредством принятия постановлений Правительства России, издания министерствами приказов и распоряжений. Как правило, указы Президента России содержат в себе организационные меры, нацеленные на реализацию резолюций. В случае необходимости нормативные акты принимаются федеральными органами исполнительной власти - это могут быть постановления, распоряжения, указания, информационные письма, письма, телеграммы и иные акты.

Так, Правительством России принято постановление об обеспечении деятельности Представительства Российской Федерации при Международной морской организации и Представительства Российской Федерации при Международной организации гражданской авиации [7], согласно которого представительство является государственным органом внешних сношений Российской Федерации, обеспечивающим участие Российской Федерации в этой международной организации в целях защиты национальных интересов в сфере международного морского судоходства и защиты морской среды от загрязнения, а также в целях изучения и обобщения опыта мирового морского судоходства и международных правовых норм для применения их в практике российского морского судоходства.

В число функций представительства входит представительство Российской Федерации в Международной организации гражданской авиации и ее органах (Совете, Секретариате, Аэронавигационной комиссии, комитетах и иных рабочих органах) в целях защиты интересов и продвижения позиции Российской Федерации в области гражданской авиации. В процессе осуществления своей деятельности представительство направляет в Министерство транспорта Российской Федерации, Министерство иностранных дел Российской Федерации и Федеральную аэронавигационную службу документы и рабочие материалы, адресуемые Секретариатом Международной организации 
гражданской авиации государствам - членам организации; аналитическую информацию и предложения, связанные со всеми аспектами деятельности Международной организации гражданской авиации и представляющие интерес для Российской Федерации; ежегодные итоговые отчеты о работе Представительства [6].

На уровне федеральных министерств и ведомств принимаемые нормативные акты в сфере деятельности ИКАО, в основном, касаются вопросов организационно-технического характера: тестировании членов летных экипажей воздушных судов гражданской авиации Российской Федерации на определение уровня владения авиационным английским языком по шкале ИКАО [8], образование Межведомственной комиссии по делам Международной организации гражданской авиации [9], порядок составления, утверждения и ведения бюджетных смет Представительства Российской Федерации при Международной организации гражданской авиации, допуск аэродромов к эксплуатации по категориям ИКАО [10] и т.д.

К примеру, приказом Росавиации утвержден перечень дополнительных мер по обеспечению безопасности полетов и соблюдению стандартов ИКАО при выполнении международных полетов [11]: ежеквартальная публикация на официальном сайте Росавиации информации о наиболее характерных замечаниях, выявленных инспекторами Еврокомиссии при проведении проверок российских воздушных судов по программе оценки безопасности иностранных воздушных судов (SAFA) в аэропортах Европейского Союза, оперативное приведение парка эксплуатируемых воздушных судов учреждений в соответствие с требованиями ИКАО и т.д.

Распоряжением Росавиации [12] в сфере применения стандартов и процедур ИКАО предложено при проектировании и эксплуатации аэродромов и вертодромов, используемых для полетов гражданских воздушных судов, в случае отсутствия нормативных требований в документах Российской Федерации использовать положения приложения 14 «Аэродромы» к Конвенции о международной гражданской авиации, при выполнении перевозок опасных грузов воздушным транспортом руководствоваться положениями приложения 18 «Безопасная перевозка опасных грузов» к Конвенции о международной гражданской авиации.

Исходя из анализа деятельности Международной организации гражданской авиации и принимаемых на основании них в Российской Федерации нормативных правовых актов, можно прийти к следующему. Налицо серьезная работа всего государственного аппарата Российской Федерации по исполнению стандартов и рекомендаций ИКАО: начиная от организации работы представительства Российской Федерации в ИКАО и заканчивая проектированием, эксплуатацией воздушных судов, аэродромов в соответствии с Конвенцией международной гражданской авиации. Нормативные правовые акты, принимаемые Российской Федерацией в свете Чикагской конвенции имеют исполнительно-распорядительный характер, несут в себе цель исполнения международных актов. Следует констатировать, что сегодня на международном уровне не принято норм, которые бы предписывали, как поступать в том случае, когда между внутригосударственным правом и международным имеются противоречия, законодательно не закреплена последовательность действий стран-участников в данном случае. Вопрос оставлен на усмотрение каждого государства. Считаем, что в данном случае должен соблюдаться принцип добровольного исполнения обязательств страной-участником.

\section{Библиографический список}

1. Послание Президента РФ В.В. Путина Федеральному Собранию РФ от 1 марта 2018 г. // [Электронный ресурс]. - Режим доступа: справочно-правовая система «Гарант».

2. Официальный сайт Организации Объединенных Наций [Электронный ресурc]. URL: www.un.org/ru/ecosoc/ icao/.

3. Бордунов В. По рецептам ИКАО. Какую систему безопасности полетов предполагается ввести в России // Юрист спешит на помощь. 2014. № 9.

4. Конвенция о международной гражданской авиации, заключена в г. Чикаго 07.12.1944 // [Электронный ресурс]. - Режим доступа: справочно-правовая система «Гарант».

5. Рухлинский В.М. Государственное регулирование деятельности гражданской авиации России в сфере требований ИКАО // Транспортное право. 2014. № 2. С. 25. 
6. Соловьева Т.Л. Влияние международных организаций гражданской авиации на формирование нормативной правовой базы обеспечения безопасности воздушного транспорта// Транспортное право. 2008. № 4 .

7. Постановление Правительства РФ от 02.06.2006 № 348 «Об обеспечении деятельности Представительства Российской Федерации при Международной морской организации и Представительства Российской Федерации при Международной организации гражданской авиации» // Собрание законодательства РФ. Москва. 2006. № 24. Ст. 2601.

8. Приказ Федерального агентства воздушного транспорта от 26.04.2018 № 353-П «Об утверждении Методических рекомендаций о тестировании членов летных экипажей воздушных судов гражданской авиации Российской Федерации на определение уровня владения авиационным английским языком по шкале ИКАО» // [Электронный ресурс]. - Режим доступа: справочно-правовая система «Консультант Плюс».

9. Приказ Минтранса России от 17.10.2016 № 293 «Об утверждении Порядка составления, утверждения и ведения бюджетных смет Министерства транспорта Российской Федерации, Представительства Российской Федерации при Международной морской организации, Представительства Российской Федерации при Международной организации гражданской авиации и федеральных казенных учреждений, находящихся в ведении Министерства транспорта Российской Федерации» // [Электронный ресурс].- Режим доступа: справочно-правовая система «Консультант Плюс».

10. Распоряжение Росавиации от 16.12.2009 « ГК-272-р «О допуске аэродрома Санкт-Петербург (Пулково) к эксплуатации по І категории ИКАО с МКпос - $97^{\circ}$ лев.; $277^{\circ}$ пр.; $97^{\circ}$ пр.; $277^{\circ}$ лев.; к эксплуатации по II категории ИКАО с МКпос $-97^{\circ}$ лев.; $277^{\circ}$ пр.; $97^{\circ}$ пр. и к эксплуатации по III-А категории ИКАО с МКпос- $97^{\circ}$ лев.; $277^{\circ}$ пр.» // [Электронный ресурс]. - Режим доступа: справочно-правовая система «Консультант Плюс».

11. Приказ Росавиации от 26.05 .2011 № 292 «О дополнительных мерах по обеспечению безопасности полетов и соблюдению стандартов ИКАО при выполнении международных полетов» // [Электронный ресурс].- Режим доступа: справочно-правовая система «Консультант Плюс».

12. Распоряжение Росавиации от 14.07.2006 № АЮ-225-р «О применении стандартов и процедур ИКАО» // [Электронный ресурс]. - Режим доступа: справочно-правовая система «Консультант Плюс». 